11. Bersenev, V. P. (1986). Diahnostika i khirurhicheskoe lechenie povrezhdenii perifericheskich nervov konechnostei [Diagnosis and surgical treatment of nerve damage of extremities]. Leningrad, 36.
12. De Franco, M. J., Lawton, J. N. (2006). Radial Nerve Injuries Associated With Humeral Fractures. The Journal of Hand Surgery, 31 (4), 655-663. doi: 10.1016/j.jhsa. 2006.02 .013

Дата надходження рукопису 13.10.2015

Вишневский Виктор Александрович, заслуженный врач Украины, доктор медицинских наук, доцент, ГУ «Днепропетровский медицинский институт традиционной и нетрадиционной медицины» МЗО Украины, ул. Севастопольская, 17, г. Днепропетровск, Украина, 49005

главврач, КУ «Днепропетровская городская клиническая больница № 16, ДОС»», ул. Героев Сталинграда, 19, г. Днепропетровск, Украина, 49068

E-mail: vishnevskiy@pochta.com

УДК 616.839-06:616.12-008.313-02:613.6]-092.9

DOI: $10.15587 / 2313-8416.2015 .54021$

\title{
РОЛЬ БЕТА1-АДРЕНОРЕЦЕПТОРІВ ЗОРОВОЇ АСОЩАТИВНОЇ КОРИ ЩУРІВ РІЗНОГО ВІКУ У ВПЛИВІ НА АВТОНОМНУ РЕГУЛЯЦІЮ СЕРЦЕВОГО РИТМУ ЗА УМОВ ЗНИЖЕНОГО АТМОСФЕРНОГО ТИСКУ
}

\section{(C) Н. М. Волкова}

У інтактних щурів бета 1-рецепторні структури лівого і правого асоціативного кіркового поля Ос $2 \mathrm{~L}$ включені до нейронних ланџюгів, які забезпечують зростання напруження процесів регуляиії сериевого ритму. Після гіпоксичного впливу бета1-адренорецепторні структури лівого поля Ос2L включаються до інших нейронних ланиююгів, і беруть участь в обмеженні функиіонального напруження процесів регуляції сериеевого ритму

Ключові слова: бета1-адренорецеептори, знижений атмосферний тиск, автономна регуляція сериеевого ритму, асочіативна кора

The role of betal-adrenoreceptors at visual associative cortex in rats of different age in the impact on autonomous regulation of the heart rate ander low atmospheric pressure was investigated. The aim of the study was to check expediency of application nebivolol to prevent the adverse effects of hypoxic environment, the pressure conditions similar to the third type of weather.

Methods. In the experimental group cardiointervalography recorded in the intact condition before hypoxia, after hypoxic exposure, after trepanation of the skull and applying the solution betal-blocker nebivolol (0.5 mg/kg) through the trepanation hole on the surface of the cerebral cortex (there were separate groups with right-sided and left-sided trepanation in projection of cortical areas Oc2L), with subsequent automatic analysis of data on a personal computer. In the control group a similar procedure of the experiment was carried out excepting hypoxic exposure. Effect of hypoxic atmosphere was created by reducing pressure by $50.76 \mathrm{hPa}$ (0.05 atm) in the Komovsky's device and hold the anesthetized rat under a glass bell for 1 hour.

Results. In juvenile, adult and old intact rats betal-receptor structures in left and right associative cortical fields Oc2L are included to the neural circuits that provide growth of functional strenuousness in regulation of heart rhythm. After hypoxic exposure betal-adrenoreceptors in the left field Oc2L are included in other neural circuits, and take part in limiting the functional strenuousness in regulation of heart rhythm.

Conclusions. Experimental results about effectiveness of therapeutic doses of beta-1 adrenoblockers especially nebivolol in adult and old age for prevention of unfavorable effects of hypoxic medium that corresponds to the baric conditions of 111type weather are to be verified by the clinical observations

Keywords: betal-Adrenergic receptors, decreased atmospheric pressure, heart autonomic regulation, associative cortex

\section{1. Вступ}

Вплив зниженого атмосферного тиску є важливим компонентом гіпоксичного ефекту атмосфери при III типі погоди [1]. Відомо про зниження розумової працездатності у метеочутливих осіб [2], що зумовлене явищами десинхронозу у функціонуванні центральних регуляторних механізмів автономного контролю, зменшенням швидкості кровотоку в середній і задній мозкових артеріях, які кровопостачають конвекситальні відділи тім'яної асоціативної кори зліва, відбувається перерозподіл крові до правої півкулі мозку [3]. 
Для обрання оптимальних засобів корекції розумової працездатності метеочутливих осіб необхідно дослідити на біологічній моделі як змінюється функціональна активність медіаторчутливих структур асоціативних полів кори великих півкуль, за умов зниженого атмосферного тиску, і їх роль у впливі на автономну регуляцію серцевого ритму.

\section{2. Обгрунтування дослідження}

Дослідження ролі медіаторних систем асоціативної кори на експериментальній моделі, а саме в щурів різного віку, у впливі на автономну регуляцію серцевого ритму за умов зниженого атмосферного тиску, подібних до баричних умов III типу погоди, дозволить оцінити можливість фармакологічної корекції функціонального стану метеочутливих осіб. В літературі зустрічаються дані про зниження чутливості холінорецепторів у мембранних структурах кори великих півкуль за умов гіпоксичного впливу в експерименті [4], але обмаль даних про стан бета1-адренорецепторів. Водночас відомо про участь бета-1-адренорецепторних зв'язків у забезпеченні когнітивних функцій [5], але не з'ясовані функціональні зміни за умов гіпобаричної гіпоксії. Літературні джерела повідомляють, що небіволол $є$ конкурентним і селективним блокатором бета1-адренергічних рецепторів та підвищує реакцію судин на ацетилхолін, опосередковану монооксидом азоту $[6,7]$. Отже, доцільно вивчити ефекти небівололу на рецепторні структури асоціативної кори за умов зниженого атмосферного тиску в експерименті.

\section{3. Мета дослідження}

Експерименти здійснили для вивчення ролі бета1-адренорецепторів зорової асоціативної кори щурів різного віку у впливі на автономну регуляцію серцевого ритму за умов зниженого атмосферного тиску з метою перевірити доцільність застосування небівололу для попередження несприятливих наслідків гіпоксичного середовища, подібного до баричних умов III типу погоди.

\section{4. Матеріали і методи}

Дослідження проведені на базі наукової лабораторії ННІ моделювання та аналізу патологічних процесів, який $є$ структурним підрозділом ДВНЗ «Тернопільський державний медичний університет ім. І. Я. Горбачевського МОЗ України».

При обранні для впливу ділянки асоціативної кори враховували дані літератури [8], де показано наслідки експериментальної оклюзії середньої мозкової артерії у щурів, зокрема підтверджено понад 90 \% пошкоджень у кіркових полях Par1, Te1, Te2, Te3, Oc1B, Oc2L. Нами було обрано для дослідження асоціативне поле Oc2L, яке є вторинним зоровим полем, анатомічно найбільш доступне для експерименту [9] і може слугувати біологічною моделлю функціональних змін у паріетальній корі людини за умов гіпоксичного ефекту атмосфери при III типі погоди. В дослідженні враховували вікові особливості центральних регуляторних механізмів автономного контролю.

Експериментальні дослідження проведені на нелінійних щурах обох статей трьох вікових груп: молодих до настання статевої зрілості віком 11,5 місяці масою 70-100 г, статевозрілих дорослих віком 6-8 місяців масою 175-230 г. і старих віком 10-12 місяців масою 250-350 г. Усього в експериментальних дослідженнях використано 60 тварин. Усіх тварин утримували на стандартному раціоні віварію. Дослідження виконували відповідно до “Загальних етичних принципів експериментів на тваринах”, ухвалених Першим національним конгресом 3 біоетики (Київ, 2001) та узгоджених 3 положеннями “Європейської конвенції щодо захисту хребетних тварин, які використовуються для експериментальних і інших наукових цілей” (Страсбург, 1986).

В експериментальній групі (по 10 молодих, старих і дорослих тварин відповідно) реєстрували кардіоінтервалограму в інтактному стані до гіпоксіі, після гіпоксичного впливу, після трепанації черепа і нанесення розчину бета1-адреноблокатору небівололу $(0,5$ мг/кг) через трепанаційний отвір на поверхню кори великих півкуль (були окремі групи з правобічною і з лівобічною трепанацією в проекції кіркової ділянки Oc2L), із подальшим автоматичним аналізом даних на персональному компьютері. В контрольній групі (по 10 тварин молодих, старих і дорослих тварин відповідно) здійснили аналогічний порядок експерименту, за виключенням гіпоксичного впливу.

Вплив гіпоксичної атмосфери за умов зниженого атмосферного тиску, аналогічних до природних умов III типу погоди [1], створювали за допомогою зниження тиску на 50,76 гПа (0,05 атм.) в апараті Комовського й утримування занаркотизованого щура під скляним дзвоном протягом 1 год. Тривалість перебування щура у гіпобаричному середовищі обрали, враховуючи дані літератури про тривалість функціональних змін та регуляторні наслідки гіпоксичного впливу на тканину мозку, що вирішує питання формування довготривалої адаптації чи розвиток порушення функції із наступними патогенетичними змінами [10].

Стан напруження процесів автономної регуляції оцінювали за допомогою методу дослідження варіабельності серцевого ритму [11]. При аналізі результатів кардіоінтервалогафії обраховували середнє значення тривалості кардіоциклу, стандартне відхилення, варіаційний розкид, моду, амплітуду моди, індекс напруження (IH), вегетативний показник ритму. Статистичну обробку здійснили на персональному компьютері за допомогою критеріїв параметричної i непараметричної статистики. Критичний рівень значимості $\mathrm{p}=0,05$.

\section{5. Результати дослідження}

У молодих, дорослих і старих тварин після перебування в гіпоксичному середовищі виявлене суттєве зниження IH, порівняно з інтактними щурами. Введення розчину небівололу після отримання 
гіпоксії в жодній групі тварин не відновлювало того рівня напруження процесів регуляції, якій спостерігався у інтактних щурів на початку експерименту.

Після гіпоксичного впливу у молодих щурів нанесення розчину небівололу на праве кіркове поле викликало суттєве зниження IH, а на ліве підвищення IН. На відміну від цього, у інтактних молодих щурів лівобічний вплив небівололу призводив до більш інтенсивної відповіді, порівняно до правобічного, і в обох випадках IH знижувався. Подібна динаміка змін IH спостерігалася у дорослих і старих щурів.

В експерименті виключення бета1-адренорецепторів в асоціативній корі дорослих щурів за умов зниженого атмосферного тиску виявило залучення бета1-адренергічних структур досліджуваного лівого асоціативного кіркового поля Oc2L до нейронних ланцюгів, які створювали парасимпатичний вплив на серцевий ритм, що відрізнялося від ефекту небівололу при нормальному атмосферному тиску.

У старих щурів після гіпоксії лівобічний вплив небівололу призводив до більшого значення IH, ніж після правобічного впливу, але ці показники були менші за рівень ІН після гіпоксії без небівололу (рис. 1).

нами суттєве зниження ІН після гіпоксичного впливу у щурів усіх вікових груп свідчить про включення адаптивних енергозберігаючих механізмів регуляції серцевого ритму, що водночас опосередковано зменшує кровопостачання асоціативної кори і в такий спосіб обмежує функціональні можливості нервової системи.

Виключення бета1-адренорецепторів в асоціативній корі щурів молодого віку не може суттєво компенсувати регуляторні впливи на серцевий ритм, які відбулися при інкубації в гіпоксичному середовищі за умов зниженого атмосферного тиску. У молодих, дорослих і старих інтактних щурів бета1-рецепторні структури лівого і правого асоціативного кіркового поля Oc2L включені до нейронних ланцюгів, які забезпечують зростання напруження процесів регуляції серцевого ритму, про що свідчить зниження IH при їх виключенні. Після гіпоксичного впливу бета1-адренорецепторні структури лівого поля Oc2L включаються до інших нейронних ланцюгів, і беруть участь в обмеженні функціонального напруження процесів регуляції серцевого ритму. Блокування бета1-адренорецепторів зорової асоціативної кори справа дозволяє виявити активацію холінергічних зв’язків правої асоціативної кори з підкірковими парасимпатичними центрами.

В літературі показано, що протягом впливу гіпоксичного середовища найшвидше знижується поступлення кисню до кори великих півкуль, тому існує необхідність терапевтичного впливу на тканину кори для попередження гіпоксії, зокрема у дитячому віці [12]. 3 літератури відомо про незрілість системи неспецифічної активації ретикулярної формації стовбура головного мозку у дітей, і що у них остаточно не сформовані шляхи холінергічної передачі для аферентної стимуляції нейронів неокортексу [13], слабо виражені функціональні властивості наднирників і виробляється обмаль статевих гормонів, що має наслідком меншу щільність адренорецепторів у тканині головного мозку.

За нашими даними вплив небівололу на праве кіркове поле у молодих щурів викликає дуже значне зниження IH. Це створює несприятливі функціональні умови в організмі. Аналіз наших екс-

Примітки:

* - $<<0,05$ порівняно з інтактними щуурами;

\#- $<<0,05$ порівняно з молодими щурами;

“- $p<0,05$ порівняно зі станом одразу після гіпоксичного впливу;

$=-p<0,05$ порівняно з лівобічним введенням речовини

\section{6. Обговорення результатів}

Відомо про важливу роль симпатичної регуляції для виконання розумового навантаження. Тому при інтерпретації результатів, отриманих на біологічній моделі, звертали увагу на експериментальні умови, які сприяли зростанню IН. Виявлене периментальних даних і літературних джерел не дозволяе рекомендувати застосування небівололу для усунення метеотропних реакцій у дітей.

Значення адренергічних механізмів у регуляції серцевого ритму зростає із віком. За даними літератури, гіпоксичний вплив на тканину голов- 
ного мозку у старечому віці викликає прискорення процесів старіння, незворотні зміни у тканині кори великих півкуль і веде до розвитку захворювань, пов'язаних із віком, що потребує застосовувати терапевтичні заходи [14].

У дорослому і старечому віці метеочутливим особам, відповідно до індивідуальних проявів метеотропних реакцій, доцільно призначати бета1-адреноблокатори у терапевтичних дозах, зокрема небіволол, оскільки препарат викликає адаптивні зміни як для центральної гемодинаміки, так і на рівні медіаторного впливу на мембранні структури асоціативних ділянок кори великих півкуль. Подібний висновок про можливість застосування небівололу 3 метою попередження процесів апоптозу у тканині головного мозку зустрічаємо в літературі [15]. Доцільно шукати засоби латерального впливу на функціонування лівої асоціативної кори, наприклад, через сенсорне подразнення правого зорового поля. В літературі показано можлівість модуляції функції зорової та слухової уваги через застосування латералізованих подразників [16]. Зустрічаються дані про можливість покращити функції асоціативної зорової кори за допомогою латералізованого фізіотерапевтичного впливу [17].

\section{7. Висновки}

1. У молодих, дорослих і старих інтактних щурів бета1-рецепторні структури лівого і правого асоціативного кіркового поля Oc2L включені до нейронних ланцюгів, які забезпечують зростання напруження процесів регуляції серцевого ритму, про що свідчить зниження ІН при їх виключенні.

2. Після гіпоксичного впливу бета1-адренорецепторні структури лівого поля Ос2L включаються до інших нейронних ланцюгів, і беруть участь в обмеженні функціонального напруження процесів регуляції серцевого ритму.

3. Отримані нами експериментальні результати щодо ефективності у дорослому і старечому віці терапевтичних доз бета1-адреноблокаторів, зокрема небівололу, для попередження несприятливих наслідків впливу гіпоксичного середовища, яке відповідне до баричних умов III типу погоди, доцільно перевірити за допомогою клінічних спостережень.

\section{Література}

1. Ермакова, Л. Н. Влияние метеорологических условий на самочувствие человека [Текст] / Л. Н. Ермакова, Е. С. Ермакова // Географический вестник. - 2012. - № 2 (21). - С. 45-52.

2. Волкова, Н. М. Особливості автономної регуляції виконання розумового навантаження за несприятливих метеоумов [Текст] / Н. М. Волкова // Буковинський медичний вісник. - 2009. - Т. 13, № 2. - С. 16-18.

3. Волкова, Н. М. Роль автономної регуляції у механізмах метеотропних реакцій практично здорових дорослих осіб [Текст] / Н. М. Волкова // Довкілля та здоров’я. 2009. - № 1 (48). - C. 18-21.

4. Anju, T. R. Decreased cholinergic function in the cerebral cortex of hypoxic neonatal rats: role of glucose, oxy- gen and epinephrine resuscitation [Text] / T. R. Anju, S. Smijin, R. Chinthu, C. S. Paulose // Respiratory Physiology \& Neurobiology. - 2012. - Vol. 180, Issue 1. - P. 8-13. doi: 10.1016/ j.resp.2011.08.013

5. Gliebus, G. The influence of beta-blockers on delayed memory function in people with cognitive impairment [Text] / G. Gliebus, C. F. Lippa // American Journal of Alzheimer's Disease and Other Dementias. - 2007. - Vol. 22, Issue 1. - P. 57-61. doi: $10.1177 / 1533317506295889$

6. Münzel, T. Nebivolol: the somewhat-different beta-adrenergic receptor blocker [Text] / T. Münzel, T. Gori // Journal of the American College of Cardiology. - 2009. - Vol. 54, Issue 16. P. 1491-1499. doi: 10.1016/j.jacc.2009.05.066

7. Kamp, O. Nebivolol: haemodynamic effects and clinical significance of combined beta-blockade and nitric oxide release [Text] / O. Kamp, M. Metra, S. Bugatti, L. Bettari, A. Die Cas, N. Petrini, L. Die Cas // Drugs. - 2010. - Vol. 70, Issue 1. P. 41-56. doi: 10.2165/11530710-000000000-00000

8. Zhao, W. Transient Middle Cerebral Artery Occlusion by Intraluminal Suture: II. Neurological Deficits, and Pixel-Based Correlation of Histopathology with Local Blood Flow and Glucose Utilization [Text] / W. Zhao, L. Belayev, M. D. Ginsberg // Journal of Cerebral Blood Flow and Metabolism. - 1997. Vol. 17. - P. 1281-1290. doi: 10.1097/00004647-199712000-00003

9. Paxinos, G. The rat brain in stereotaxic coordinates [Text] / G. Paxinos, Ch. Watson. - United States of America, 1997. - 25 p. - Available at: http://www.callisto-science.org/NSI/ Neuroscience_Image_Database/PDFFILES/RBSC_INT.PDF

10. Intermittent Hypoxia and Human Diseases [Text] / L. Xi, T. V. Serebrovskaya (Eds.). - Springer Science \& Business Media. - London, 2012. - 316 p. doi: 10.1007/978-1-4471-2906-6

11. Коркушко, О. В. Значение анализа вариабельности ритма сердца в кардиологии: возрастные аспекты [Текст]/ О. В. Коркушко, А. В. Писарук, В. Б. Шатило // Кровообіг та гемостаз. - 2009. - Т. 1, № 2. - С. 127-139.

12. Dalmases, M. Brain tissue hypoxia and oxidative stress induced by obstructive apneas is different in young and aged rats [Text] / M. Dalmases, M. Torres, L. Márquez-Kisinousky // Sleep. - 2014. - Vol. 37, Issue 07. - P. 1249-1256. doi: $10.5665 /$ sleep. 3848

13. Сторожук, В. М. Роль ацетилхолина в модуляции активности нейронов неокортекса бодрствующего животного при реализации инструментального условного рефлекса [Текст] / В. М. Сторожук // Нейрофизиология. - 2009. - Т. 41, № 2. - C. 144-159.

14. Rapino, C. HIF-1alpha cytoplasmic accumulation is associated with cell death in old rat cerebral cortex exposed to intermittent hypoxia [Text] / C. Rapino, G. Bianchi, C. Di Giulio, L. Centurione, M. Cacchio, A. Antonucci, A. Cataldi // Aging Cell. 2005. - Vol. 4, Issue 4. - P. 177-185. doi: 10.1111/j.1474-9726. 2005.00161.x

15. Uzar, E. The anti-oxidant and anti-apoptotic effects of nebivolol and zofenopril in a model of cerebral ischemia/ reperfusion in rats [Text] / E. Uzar, A. Acar, O. Evliyaoğlu, U. Fırat, K. Kamasak, C. Göçmez et. al // Progress in Neuro-Psychopharmacology and Biological Psychiatry. - 2012. - Vol. 36, Issue 1. - P. 22-28. doi: 10.1016/j.pnpbp.2011.08.011

16. Fairhall, S. L. Spatial attention can modulate audiovisual integration at multiple cortical and subcortical sites [Text] / S. L. Fairhall, E. Macaluso // European Journal of Neuroscience. - 
2009. - Vol. 29, Issue 6. - P. 1247-1257. doi: 10.1111/j.14609568.2009.06688.x

17. Zito, G. A. Cathodal HD-tDCS on the right V5 improves motion perception in humans [Text] / G. A. Zito, T. Senti, D. Cazzoli, R. M. Müri, U. P. Mosimann, T. Nyffeler, T. Nef // Frontiers in Behavioral Neuroscience. - 2015. - Vol. 9. doi: 10.3389/ fnbeh.2015.00257

\section{References}

1. Ermakova, L. N., Ermakova, E. S. (2012). Influence of meteorological conditions on the well-being. Geographical Journal, 2 (21), 45-52.

2. Volkova, N. M. (2009). Features of autonomous regulation of mental performance in adverse weather conditions load Bukovina Medical Journal, 13 (2), 16-18.

3. Volkova, N. M. (2009). The role of autonomous regulation mechanisms of meteotropic reactions in healthy adults. Environment and Health, 1 (48), 18-21.

4. Anju, T. R., Smijin, S., Chinthu, R., Paulose, C. S. (2012). Decreased cholinergic function in the cerebral cortex of hypoxic neonatal rats: Role of glucose, oxygen and epinephrine resuscitation. Respiratory Physiology \& Neurobiology, 180 (1), 8-13. doi: 10.1016/j.resp.2011.08.013

5. Gliebus, G., Lippa, C. F. (2007). The Influence of betaBlockers on Delayed Memory Function in People With Cognitive Impairment. American Journal of Alzheimer's Disease and Other Dementias, 22 (1), 57-61. doi: 10.1177/1533317506295889

6. Münzel, T., Gori, T. (2009). Nebivolol: the somewhatdifferent beta-adrenergic receptor blocker. Journal of the American College of Cardiology, 54 (16), 1491-1499. doi: 10.1016/ j.jacc.2009.05.066

7. Kamp, O., Metra, M., Bugatti, S., Bettari, L., Dei Cas, A., Petrini, N., Dei Cas, L. (2010). Nebivolol. Drugs, 70 (1), 4156. doi: 10.2165/11530710-000000000-00000

8. Zhao, W., Belayev, L., Ginsberg, M. D. (1997). Transient Middle Cerebral Artery Occlusion by Intraluminal Suture: II. Neurological Deficits, and Pixel-Based Correlation of Histopathology with Local Blood Flow and Glucose Utilization. Journal of Cerebral Blood Flow and Metabolism, 17, 1281-1290. doi: 10.1097/00004647-199712000-00003
9. Paxinos, G., Watson, Ch. (1997). The rat brain in stereotaxic coordinates. United States of America, 25. Available at: http://www.callisto-science.org/NSI/Neuroscience_Image_Database/PDFFILES/RBSC_INT.PDF

10. Xi, L., Serebrovskaya, T. V. (2012). Intermittent Hypoxia and Human Diseases. Springer Science \& Business Media, 316. London, 316. doi: 10.1007/978-1-4471-2906-6

11. Korkushko, A. V., Pisaruk, A. V., Shatylo, V. B. (2009). Value analysis of heart rhythm variability in Cardiology. Circulation age aspects and hemostasis,1 (2), 127-139.

12. Dalmases, M., Torres, M., Márquez-Kisinousky, L. (2014). Brain tissue hypoxia and oxidative stress induced by obstructive apneas is different in young and aged rats. Sleep, 37 (07), 1249-1256. doi: 10.5665/sleep.3848

13. Storozhuk, V. M. (2009). Role of acetylcholine in modulating the activity of neurons in the neocortex conscious animals in the implementation of instrumental conditioned reflex. Neurophysiology, 41 (2), 144-159.

14. Rapino, C., Bianchi, G., Di Giulio, C., Centurione, L., Cacchio, M., Antonucci, A., Cataldi, A. (2005). HIF-1alpha cytoplasmic accumulation is associated with cell death in old rat cerebral cortex exposed to intermittent hypoxia. Aging Cell, 4 (4), 177-185. doi: 10.1111/j.1474-9726.2005. 00161.x

15. Uzar, E., Acar, A., Evliyaoğlu, O., Fırat, U., Kamasak, K., Göçmez, C. et. al (2012). The anti-oxidant and anti-apoptotic effects of nebivolol and zofenopril in a model of cerebral ischemia/reperfusion in rats. Progress in Neuro-Psychopharmacology and Biological Psychiatry, 36 (1), 22-28. doi: 10.1016/ j.pnpbp.2011.08.011

16. Fairhall, S. L., Macaluso, E. (2009). Spatial attention can modulate audiovisual integration at multiple cortical and subcortical sites. European Journal of Neuroscience, 29 (6), 1247-1257. doi: 10.1111/j.1460-9568.2009.06688.x

17. Zito, G. A., Senti, T., Cazzoli, D., Müri, R. M., Mosimann, U. P., Nyffeler, T., Nef, T. (2015). Cathodal HDtDCS on the right V5 improves motion perception in humans. Frontiers in Behavioral Neuroscience, 9. doi: 10.3389/fnbeh.2015.00257

Дата надходження рукопису 07.10.2015

Волкова Наталія Михайлівна, доктор медичних наук, доцент, кафедра фізіології, ДВНЗ «Тернопільський державний медичний університет ім. І. Я. Горбачевського МОЗ України», майдан Волі, 1, м. Тернопіль, Україна, 46001

E-mail: volkova@tdmu.edu.ua 